\section{The Impact of Alcohol on Admissions to a Welsh Intensive Care Unit: A Short Report}

\author{
Keywords: Alcohol; Alcohol-attributable outcomes; Socia \\ deprivation.

\begin{abstract}
Introduction: The average annual number of alcohol-related hospital admissions for residents of Wales is reported to be $1.5 \%$ of all admissions. We have completed a prospective evaluation of the impact of alcohol-attributable admissions to an ICU in a major tertiary centre in Wales.
\end{abstract}

Methods: Data were collected for 124 consecutive admissions to the ICU. Each admission was screened for alcohol-attributable associationsand data recorded for patient characteristics, demographics and outcomes.

Results: A total of 124 patients were included, with 23 (18.5\%) admissions attributable to alcohol. The alcohol-attributable admissions were significantly younger with a higher level of deprivation (both $p<0.05)$

Discussion: Almost one fifth of admissions to our ICU were attributable to alcohol, representing a substantial impact of alcoholattributable disease on intensive care resources in South West Wales.

\section{Introduction}

The harmful use of alcohol has been associated with 3.3 million deaths each year worldwide, which represents $5.9 \%$ of all deaths [1]. Alcohol-related deaths rates were significantly higher in Wales than in England in 2012, with 18.0 compared to 14.7 per 100,000, respectively [2]. Previous studies have reported that social deprivation is reported to influence alcohol-related mortality. The alcohol-related mortality rate in low income areas of Wales was 22.0 per 100,000 in 2002-2006, more than three times higher than the least deprived areas [3]. We undertook a prospective pilot study to describe alcohol-attributable admissions to an ICU in a majortertiary centre in Wales.

\section{Methods}

Data collection was completed from $20^{\text {th }}$ November, 2014 until $31^{\text {st }}$ December, 2014. Re-admissions to the ICU during the same hospital stay were excluded. Ethical approval was waived (Wales REC 6). Each consecutive admission was prospectively screened using the patient's medical notes for direct or indirect alcohol associations (defined as alcohol-attributable admissions) according to predetermined definitions based on the ICD-10 criteria, outlined in a similar study [4]. The Ward-Watcher database (Critical Care Audit Limited, Ilkley, UK) was used to obtain patient outcomes.

Using the patient's postcode, a deprivation code was assigned using the Welsh Index of Multiple Deprivation [5]. Eight domains of deprivation are included andeach domain is made up of a number of indicators, highlighted in Table 1.

\section{Journal of}

\section{Emergency Medicine \& Critical Care}

\section{Ceri Battle ${ }^{1^{*}}$, Morgan Pengelly ${ }^{2}$, Karen James ${ }^{1}$, Abigail Clayton $^{1}$ and Craig Jerwood ${ }^{1}$}

${ }^{\prime}$ Ed Major Critical Care Unit, Morriston Hospital, Swansea, UK ${ }^{2}$ College of Medicine, University of Otago, Otago, New Zealand

\section{Address for Correspondence}

Ceri Battle, Department of Physiotherapy, Ed Major Critical Care Unit, Morriston Hospital, Morriston, Swansea, SA6 6NL, UK, Tel: 00441792 703124; E-mail: Ceri.battle@wales.nhs.uk

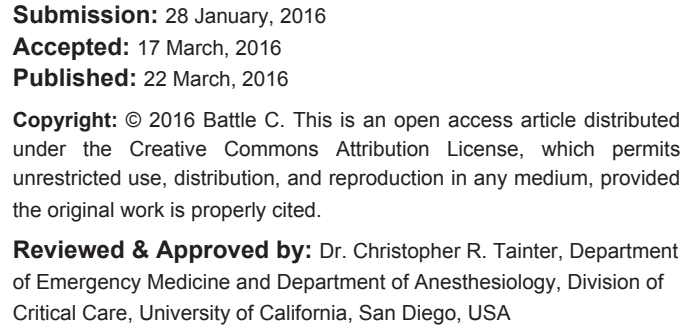

Reviewed \& Approved by: Dr. Christopher R. Tainter, Department of Emergency Medicine and Department of Anesthesiology, Division of Critical Care, University of California, San Diego, USA

The income domain indicator was used as a marker of deprivation in this study as it is an absolute score which provides the percentage of those living in the area receiving income related benefits and has an extremely high correlation with the overall deprivation index [5].

Results were presented as medians and inter quartile ranges (IQR) for continuous data (due to non-normal distribution) or numbers and percentages (\%) for categorical data.

\section{Results}

A total of 124 unique patients were included, with two exclusions due to re-presentation. Twenty-three (18.5\%) admissions were attributable to alcohol, Chronic alcohol-related disease was recorded in 18 (15\%) out of the 23 alcohol attributable patients. A significantly higher level of deprivation in the alcohol-attributable admissions group $(\mathrm{p}<0.05)$ was reported. Patients' characteristics and outcomes are shown in Table 2.

Table 1: Domains and indicators comprising social deprivation in Wales

\begin{tabular}{|c|c|}
\hline Domain & Indicators \\
\hline Income & $\%$ of population in receipt of income-related benefits \\
\hline Employment & $\begin{array}{l}\% \text { of working age population in receipt of employment- } \\
\text { related benefits }\end{array}$ \\
\hline Health & $\begin{array}{l}\text { All-cause death rate, cancer incidence, limiting long-term } \\
\text { illness, low birth weight rate }\end{array}$ \\
\hline Education & $\begin{array}{l}\text { Key stage } 2-4 \text { score averages, school absence rates, } \% \\
18-19 \text { years olds not entering higher education, } \% 25-64 \\
\text { year olds with no qualifications }\end{array}$ \\
\hline $\begin{array}{l}\text { Access to } \\
\text { services }\end{array}$ & $\begin{array}{l}\text { Journey time to food shop, dentist, GP, post office, leisure } \\
\text { centre, school, transport node }\end{array}$ \\
\hline Community safety & Over-crowding, central heating \\
\hline $\begin{array}{l}\text { Physical } \\
\text { environment }\end{array}$ & $\begin{array}{l}\text { Air quality / emissions, flood risk, proximity to waste and } \\
\text { industrial sites }\end{array}$ \\
\hline Housing & $\begin{array}{l}\text { Adult / youth offenders, police recorded crime rates for } \\
\text { violent crime, criminal damage, burglary and theft }\end{array}$ \\
\hline
\end{tabular}


Citation: Battle C, Pengelly M, James K, Clayton A, Jerwood C. The Impact of Alcohol on Admissions to a Welsh Intensive Care Unit: A Short Report. J Emerg Med Critical Care. 2016;2(1): 2.

ISSN: $2469-4045$

Table 2: Patients' characteristics for admission to ICU, attributable and nonattributable to alcohol.

\begin{tabular}{|l|l|l|l|l|}
\hline & $\begin{array}{l}\text { All } \\
\text { patients }\end{array}$ & $\begin{array}{l}\text { Alcohol- } \\
\text { attributable }\end{array}$ & $\begin{array}{l}\text { Non-alcohol- } \\
\text { attributable }\end{array}$ & p value \\
\hline Number & 124 & $23(18.5 \%)$ & $101(81.5 \%)$ & \\
\hline Male & $65(52 \%)$ & $17(74 \%)$ & $48(48 \%)$ & 0.036 \\
\hline APACHE II & $14(10-20)$ & $14(10-21)$ & $14(10-20)$ & 0.888 \\
\hline Age & $65(54-74)$ & $60(52-68)$ & $66(54-75)$ & 0.033 \\
\hline $\begin{array}{l}\text { Income domain } \\
\text { indicator }\end{array}$ & $15(8-26)$ & $22(15-31)$ & $13(8-24)$ & 0.001 \\
\hline ICU mortality & $23(19 \%)$ & $3(13 \%)$ & $20(20 \%)$ & 0.563 \\
\hline Hospital mortality & $31(25 \%)$ & $7(30 \%)$ & $24(24 \%)$ & 0.594 \\
\hline Ventilator days & $2(0-7)$ & $2(0-7)$ & $1(0-6)$ & 0.605 \\
\hline $\begin{array}{l}\text { ICU length of stay } \\
\text { (days) }\end{array}$ & $5(3-11)$ & $5(3-10)$ & $5(3-11)$ & 0.575 \\
\hline $\begin{array}{l}\text { Hospital length of stay } \\
\text { (days) }\end{array}$ & $15(5-30)$ & $20(5-38)$ & $13(5-28)$ & 0.221 \\
\hline
\end{tabular}

Median $\left(25^{\text {th }}-75^{\text {th }} I Q R\right)$ or number $(\%)$

\section{Discussion}

In this study, we identified that nearly 1 in 5 ICU admissions were associated with alcohol use. ICU mortality for alcohol-attributable admissions in our study was $13 \%$, compared to the overall ICU mortality of $19 \%$ and a similar result of $18 \%$ in a recent Scottish study due to alcohol [4]. Previous research has reported alcohol-related admissions are more likely to be male patients and younger compared with those without alcohol-related disease [4,6]. The results of this study supported these findings.

Previous research has highlighted an association between social deprivation and both increased ICU admission rates and ICU / hospital mortality [7,8]. This study demonstrated that patients admitted to the ICU of a Welshtertiarycentre with alcohol-attributable conditions are significantly more likely to live in an area with higher social deprivation. This result supports the finding reported by Public
Health Wales, that the most deprived areas experienced alcoholattributable mortality rates more than three times higher than the least deprived areas [9].

\section{Conclusions}

This pilot study reports the impact of alcohol on the admissions to an ICU in South Wales. The next stage of this work is to complete an all-Wales prospective evaluation of the impact of alcohol on ICU outcomes and service provision.

\section{References}

1. World Health Organisation (2015) Alcohol Fact sheet

2. Office for National Statistics (2014) Alcohol-related deaths in the United Kingdom, Registered in 2012. Statistical Bulletin.

3. The Public Health Wales Observatory (2014) Alcohol and Health in Wales 2014.

4. Geary T, O'Brien P, Ramsay S, Cook B, Scottish Intensive Care Trainees' Audit Share Group (2012) A national service evaluation of the impact of alcohol on admissions to Scottish intensive care units. Anaesthesia 67: 11321137.

5. Ystadegau ar gyfer cymru statistics for Wales (2011) Summary Report. Welsh Index of Multiple Deprivation 2011.

6. Marik P, Mohedin B (1996) Alcohol-related admissions to an inner city hospital intensive care unit. Alcohol Alcohol 31: 393-396.

7. Welch CA, Harrison DA, Hutchings A, Rowan K (2010) The association between deprivation and hospital mortality for admissions to critical care units in England. J Crit Care 25: 382-390.

8. Booth M, Murray S, Plenderleith L, Howie C, MacKirdy F (2003) Effect of socioeconomic deprivation on intensive care mortality. Crit Care 7(Suppl 2): P233.

9. National Public Health Service for Wales (2009) Profile of alcohol and health in Wales. Wales Centre for Health. 